\title{
Gambaran Subtipe HIV-1 dengan kadar CD4, Stadium Klinis, dan Infeksi Oportunistik Penderita HIV/AIDS di Kota dan Kabupaten Jayapura, Papua
}

\author{
Mirna Widiyanti, Semuel Sandy \\ Balai Litbang Biomedis Papua, Kementerian Kesehatan Republik Indonesia
}

\begin{abstract}
Abstrak
Jumlah kasus HIV/AIDS di Indonesia akhir Maret 2013 tercatat 103.759 kasus dan 43.347 kasus AIDS yang tersebar di Indonesia. Papua merupakan provinsi ketiga yang memiliki jumlah kasus HIV/AIDS cukup tinggi, yaitu 10.881 kasus HIV dan 7.795 kasus AIDS. Tujuan penelitian ini melihat distribusi subtipe HIV-1 yang dominan di Papua dan mengetahui hubungan subtipe HIV-1 dengan kadar CD4, stadium klinis, dan infeksi oportunistik penderita HIV/AIDS. Penelitian menggunakan rancangan potong lintang. Pemeriksaan subtipe HIV-1 menggunakan RT-PCR dan sekuensing. Penelitian dilaksanakan di RSUD Dok II, RS Abepura, dan RSUD Yowari Kabupaten Jayapura pada bulan November-Desember 2012. Data CD4, stadium klinis, dan jenis infeksi oportunistik dicatat melalui rekam medis pasien. Data dianalisis menggunakan uji statistik chi-kuadrat. Subtipe HIV-1 yang dominan ditemukan, yaitu CRF01_AE sebanyak 51 orang (54\%) dan subtipe B sebanyak 43 orang (46\%). Dari 94 pasien HIV sebanyak 62 orang $(66 \%)$ menderita infeksi oportunistik TB paru dan beberapa menderita lebih dari satu jenis infeksi oportunistik. Uji statistik menunjukkan tidak ada hubungan bermakna subtipe HIV-1 dengan kadar CD4 dan stadium klinis, tetapi menunjukkan korelasi bermakna terhadap infeksi oportunistik. Simpulan ditemukan subtipe HIV-1 yang dominan di Papua adalah CRF01_AE dan infeksi oportunistik terbanyak pada penderita adalah tuberkulosis. [MKB. 2016;48(1):1-6]
\end{abstract}

Kata kunci: CD4, infeksi oportunistik, stadium klinis, subtipe HIV-1

\section{Overview of HIV-1 Subtype with CD4 Levels, Clinical Stage and Opportunistic Infections HIV/AIDS in City and Regency of Jayapura-Papua}

\begin{abstract}
The number of HIV/AIDS cases recorded in March 2013 in Indonesia is 103,759 HIV cases and 43,347 AIDS cases. Papua is the province that has the third highest number HIV/AIDS cases with 10,881 HIV cases and 7,795 AIDS cases. The aim of this study was to identify the distribution of HIV-1 subtypes which are dominant in Papua and to identify opportunistic infections related to HIV/AIDS and their relationship with HIV-1 subtypes. This study is a cross-sectional study. The identification of HIV-1 was performed using nested-PCR and sequencing to look for HIV-1 subtypes. The study was conducted in Dok II, Abepura and Yowari VCT Hospital in Jayapura District during the period of November-December 2012. CD4 and opportunistic infections were retrieved from patient medical records. Data were analyzed statistically using chi-square test. The dominant HIV-1 subtypes found were subtype CRF01-AE, which was found in 51 people (54\%), and subtype B, which was found in 43 people (46\%). Of 94 HIV patients, $62(66 \%)$ respondents suffered from pulmonary tubeculosis opportunistic infection and some patients suffered more than one type of opportunistic infections. There was no significant difference found between the HIV-1 subtypes, CD4 level, and clinicial stage. However, a significant correlation with opportunistic infections was found. It is concluded that the dominant HIV-1 subtype in Papua is CRF01_AE with tuberculosis as the most frequent opportunistic infection. [MKB. 2016;48(1):1-6]
\end{abstract}

Key words: CD4, clinical stage, HIV-1 subtypes, opportunistic infection

Korespondensi: Mirna Widiyanti, S.Si, M.Sc, Balai Litbang Biomedis Papua Badan Penelitian dan Pengembangan Kesehatan Kementerian Kesehatan RI, Jalan Kesehatan No.10 Dok II Jayapura mobile 081344388000, e-mail ninawidhy@gmail.com 


\section{Pendahuluan}

Acquired immunodeficiency syndrome (AIDS) merupakan kumpulan gejala penyakit yang diakibatkan oleh infeksi human immunodeficiency virus (HIV). Virus HIV memiliki material genetik berupa dua buah positif single strand RNA yang mengkode 10 jenis gen (gag, pol, env, tat, rev, nef, vif, vpr, vpu, dan tev). Gen gag, pol, dan env adalah gen utama yang sering digunakan sebagai dasar penggolongan genotipe dan subtipe HIV. ${ }^{1}$

Di Indonesia jumlah kasus penyakit HIV/AIDS mengalami peningkatan, pada akhir Maret 2013 tercatat 103.759 kasus HIV dan 43.347 AIDS yang tersebar di Indonesia. ${ }^{2}$ HIV-1 diklasifikasikan dalam tiga grup filogenetik utama: grup M (main, major), grup 0 (outlier), dan grup N (New, non-M/ non-0). ${ }^{3-5}$ Grup $M$ tersebar luas dan merupakan penyebab paling sering epidemi HIV di seluruh dunia. Grup $M$ dibagi lagi menjadi 9 subtipe filogenetik, yaitu subtipe A, B, C, D, F, G, H, J, dan $\mathrm{K}^{6,7}$ Pada keadaan tertentu 2 virus dari subtipe berbeda dapat bertemu dalam sel tubuh orang yang terinfeksi dan bahan genetik mereka akan berekombinasi menjadi virus hibrida baru yang disebut circulating recombinant forms (CRF) dan sampai saat ini telah ditemukan sebanyak 48 CRF di dunia, di antaranya CRF03_AB (gabungan subtipe A dan B), CRF02_AG (gabungan subtipe A dan G), dan CRF01_AE (gabungan subtipe A dan E). ${ }^{8}$ Subtipe CRF01_AE paling banyak dijumpai di kawasan Asia Tenggara. ${ }^{9}$

Variasi subtipe HIV-1 dapat menjadi potensi masalah bagi kesehatan masyarakat dalam hal strategi penyebaran dan pencegahan HIV/AIDS. Subtipe HIV merupakan penanda molekuler yang penting untuk memonitor perubahan epidemi HIV di dunia. ${ }^{10}$ Subtipe HIV-1 secara global mempunyai distribusi yang berbeda antara satu daerah dan daerah lainnya, perbedaan subtipe HIV terdistribusi berdasarkan faktor geografis.

Papua merupakan provinsi ketiga yang mempunyai jumlah kasus HIV/AIDS cukup tinggi, yaitu 10.881 kasus HIV dan 7.795 kasus AIDS. ${ }^{11}$ Tingginya jumlah penderita di Papua seiring dengan maraknya pemekaran daerah serta mobilisasi penduduk yang cukup tinggi. Penelitian ini mengambil lokasi di Provinsi Papua karena penelitian gambaran subtipe HIV dengan CD4 dan infeksi oportunistik belum dilaporkan.

Infeksi oportunistik (IO) adalah infeksi yang timbul akibat penurunan kekebalan tubuh. Infeksi ini dapat timbul karena mikrob (bakteri, jamur, virus) yang berasal dari luar tubuh maupun yang sudah ada dalam tubuh. ${ }^{12}$ Penderita HIV cenderung mudah masuk dalam stadium AIDS karena mengalami infeksi oportunistik. Secara klinis digunakan hitung jumlah limfosit cluster of differentiation (CD4) sebagai petanda munculnya infeksi oportunistik terhadap penderita AIDS. Penurunan CD4 disebabkan oleh kematian CD4 yang disebabkan oleh human immunodeficiency virus. Jumlah CD4 yang normal berkisar 410$1.590 \mathrm{sel} / \mathrm{mL}$ darah. Ketika jumlahnya berada di bawah $350 \mathrm{sel} / \mathrm{mL}$ darah, kondisi tersebut sudah dianggap sebagai AIDS. Infeksi oportunistik umumnya terjadi bila jumlah CD4 $<200 \mathrm{sel} / \mathrm{mL}$ darah. Data Kementerian Kesehatan RI (2011) memperlihatkan proporsi IO pada penderita AIDS di Indonesia adalah tuberkulosis (41\%), diare kronik (25\%), kandidiasis orofaringeal $(24,6 \%)$, dermatitis generalisata $(6,1 \%)$, dan limfadenopati $(2,75 \%)$.

Penelitian ini untuk melihat distribusi subtipe HIV-1 yang dominan di Papua dan mengetahui hubungan subtipe HIV-1 dengan kadar CD4, stadium klinis, dan infeksi oportunistik penderita HIV/AIDS.

\section{Metode}

Penelitian ini dilaksanakan dari bulan JanuariMaret 2013, proses ekstraksi RNA sampel itu dilakukan di laboratorium Virologi Balai Litbang Biomedis Papua. Proses RT-PCR, nested PCR, elektroforesis, dan sekuensing dilaksanakan di Laboratorium penyakit infeksi Prof. Oemijati Badan Litbangkes Jakarta. Jenis penelitian ini adalah deskriptif analitik dengan rancangan cross sectional pada penderita yang menjalani perawatan rutin di VCT RSUD Yowari, VCT RSUD Dok II, dan VCT RSUD Abepura. Subjek penelitian adalah penderita HIV/AIDS yang dipilih secara consecutive sampling, yakni semua pasien yang menderita HIV/AIDS yang telah memenuhi kriteria inklusi. Kriteria inklusi penelitian ini adalah subjek dinyatakan positif dengan 2 rapid test dan 1 pemeriksaan ELISA. Sampel berupa plasma didapatkan dari 94 pasien yang telah menandatangani lembar persetujuan (informed consent). Persetujuan etik penelitian (ethic approval) diperoleh dari Komisi Etik Penelitian Kesehatan dan Kedokteran Fakultas Kedokteran Universitas Gadjah Mada Jogjakarta serta Komisi Etik Badan Penelitian dan Pengembangan Kesehatan Jakarta.

Pengambilan informasi dengan melihat data rekam medik dilakukan untuk mendapatkan informasi data CD4, stadium klinis, dan juga infeksi oportunistik. Tahapan pemeriksaan laboratorium meliputi proses ekstraksi yang 
Mirna Widiyanti: Gambaran Subtipe HIV-1 dengan Kadar CD4, Stadium Klinis, dan Infeksi Oportunistik Penderita HIV/AIDS

Tabel 1 Hasil Identifikasi Subtipe HIV-1 pada Penderita HIV di Kota dan Kabupaten Jayapura

\begin{tabular}{lccc}
\hline \multirow{2}{*}{ Rumah Sakit } & \multicolumn{2}{c}{ Subtipe HIV-1 } & \multirow{2}{*}{ Jumlah } \\
\cline { 2 - 3 } & CRF01_AE & B & \\
\hline RS Dok II Jayapura & 12 & 17 & 29 \\
RS Abepura Jayapura & 8 & 21 & 29 \\
RS Yowari Sentani & 31 & 5 & 36 \\
Jumlah & 51 & 43 & 94 \\
\hline
\end{tabular}

mempergunakan manual kit dengan katalog \#52906. RNA HIV diekstraksi menggunakan plasma darah dan juga diamplifikasi dengan 2 pasang primer, yaitu primer forward gp40: TCTTAGGAGCAGCAGCAAGGAAGCAACTAATGGG dan primer reverse gp 41:AACGACAAAGGTGAGT ATCCCTGCCTAA dan nested PCR primer forward gp46: $\quad$ ACAATTATTGTCTGGTATAGTGCAACCA dan primer reverse gp47: TTAAACCTATCAAGCCTCCTACTATCATA. ${ }^{13}$ Proses RT-PCR dan juga nested PCR dilakukan menggunakan superscript III one-step RT-PCR with platinum taq dengan katalog nomor 12574-026. Proses sekuensing menggunakan ABI prism 3100 genetic analyzer. Hasil sekuensing dianalisis memakai software bioedit. Tahapan yang dilakukan selama proses analisis tersebut adalah trimming (memotong) hasil sekuensing yang tidak terbaca serta menggabungkan hasil sekuens primer forward dan reverse untuk didapatkan konfirmasinya. Tahapan selanjutnya adalah proses basic local alignment search tool (BLAST), yang tujuannya agar mendapatkan genotipe dan juga subtipe virus HIV. BLAST dilakukan mempergunakan dua situs genebank untuk konfirmasi, dua situs tersebut adalah BLAST dari (National Center Biotechnology Information (NCBI) pada situs www.ncbi.nlm.nih.gov dan HIV sequence database: www.hiv.lanl.gov. Untuk dapat melihat hubungan subtipe HIV-1 dengan CD4, stadium klinis, dan infeksi oportunistik menggunakan uji statistik chi-kuadrat.

\section{Hasil}

Berdasarkan atas analisis program BLAST, hasil sekuensing isolat HIV-1 di Kota dan Kabupaten Jayapura memiliki similaritas dengan sekuens HIV-1 CRF01_AE dan sunripe B. Berikut hasil identifikasi subtipe HIV-1 pada penderita HIV di Kota dan Kabupaten Jayapura (Tabel 1).

Infeksi HIV/AIDS juga berhubungan dengan infeksi oportunistik, serta distribusi proporsi penderita HIV/AIDS berdasarkan jenis infeksi oportunistik dapat dilihat pada Tabel 2.

Tabel 2 Distribusi Proporsi Penderita AIDS berdasarkan Jenis Infeksi Oportunistik

\begin{tabular}{lcclcc}
\hline \multicolumn{1}{c}{ Jenis Infeksi Oportunistik } & $\mathbf{n}$ & $\mathbf{\%}$ & \multicolumn{1}{c}{ Jenis Infeksi Oportunistik } & $\mathbf{n}$ & $\mathbf{\%}$ \\
\hline Tuberkulosis & 62 & 66 & Uretritis gonorea (GO) & 3 & 4 \\
Anemia & 1 & 1 & Kandiloma akuminata & 1 & 1 \\
Kandidiasis oral & 2 & 3 & TB, diare kronik & 1 & 1 \\
Tinea vaginalis & 1 & 1 & Servisitis, kandidiasis, BV & 1 & 1 \\
Varisela & 1 & 1 & BV, diare akut & 1 & 1 \\
Pneumonia, kandidiasis oral & 1 & 1 & Wasting syndrome, sindrom dispepsia & 1 & 1 \\
Kandida wajah & 1 & 1 & TB, PPE, anemia & 1 \\
Tb, anemia & 1 & 1 & BV, servisitis, kandidiasis, suspek GO & 1 \\
Kandidiasis oral, anemia & 1 & 1 & TB, uretritis, GO & 1 \\
Tb, kandidiasis oral & 1 & 1 & Kandidiasis oral, uretritis, diare & 1 \\
Bakterial vaginosis & 3 & 4 & TG milier+TB kelenjar & 1 \\
Papular pepuritik erupsion & 3 & 4 & Pneumonia & 1 \\
Diare akut & 2 & 3 & & 1 \\
\hline
\end{tabular}


Mirna Widiyanti: Gambaran Subtipe HIV-1 dengan Kadar CD4, Stadium Klinis, dan Infeksi Oportunistik Penderita HIV/AIDS

Tabel 3 Hubungan Subtipe HIV-1 dengan CD4, Stadium Klinis, dan Infeksi Oportunistik

\begin{tabular}{lcccc}
\hline \multirow{2}{*}{ Variabel } & \multicolumn{2}{c}{ Subtipe } & Total & Nilai p \\
\cline { 2 - 3 } & CRF01_AE & B & & \\
\hline Kadar CD4 & $17(36 \%)$ & $21(45 \%)$ & $38(40 \%)$ & 0,14 \\
$<200 / \mathrm{mm}^{3}$ & $15(32 \%)$ & $19(40 \%)$ & $34(36 \%)$ & \\
$201-349 \mathrm{~mm}^{3}$ & $4(9 \%)$ & $4(9 \%)$ & $8(9 \%)$ & \\
$350-499 / \mathrm{mm}^{3}$ & $11(23 \%)$ & $3(6 \%)$ & $14(15 \%)$ & \\
$>500 / \mathrm{mm}^{3}$ & & & & \\
Stadium klinis & $10(21 \%)$ & $15(34 \%)$ & $25(27 \%)$ & 0,59 \\
Stadium 1 & $16(34 \%)$ & $12(26 \%)$ & $28(30 \%)$ & \\
Stadium 2 & $19(41 \%)$ & $19(40 \%)$ & $38(40 \%)$ & \\
Stadium 3 & $2(4 \%)$ & $1(2 \%)$ & $3(3 \%)$ & \\
Stadium 4 & & & & \\
Infeksi oportunistik & $20(43 \%)$ & $40(85 \%)$ & $60(64 \%)$ & $0,00^{*}$ \\
TB & $27(57 \%)$ & $7(15 \%)$ & $34(36 \%)$ & \\
Non-TB & & & & \\
\hline
\end{tabular}

Hubungan anatara subtipe HIV-1 dan CD4, stadium klinis, dan infeksi oportunistik di Kota dan Kabupaten Jayapura secara lengkap dapat dilihat pada Tabel 3 .

\section{Pembahasan}

Berdasarkan Tabel 1 dapat dilihat distribusi subtipe HIV-1 di Kota dan Kabupaten Jayapura terdapat dua jenis subtipe HIV-1, yaitu CRF01 AE sebanyak 51 subjek (54\%) dan subtipe B sebanyak 43 subjek (46\%). Ada perbedaan proporsi subjek untuk RS Dok II dan Abepura (Kota Jayapura), yakni lebih banyak ditemukan subtipe B, sedangkan RS Yowari (Kabupaten Jayapura) lebih banyak ditemukan pada subtipe CRF01_AE. Di Kabupaten Jayapura, CRF01_AE didapatkan lebih banyak dibanding dengan subtipe B, subtipe ini ditemukan pada penelitian sebelumnya juga tersebar di beberapa daerah, yaitu Bali dan Jawa Barat, ${ }^{13}$ demikian pula di Jakarta dan Jawa Timur. ${ }^{14}$ Selain itu, penelitian yang dilakukan oleh Foley dkk. ${ }^{16}$ di Timika Papua pada 16 pasien HIV juga ditemukan subtipe CRF01_AE $(87,5 \%)$ lebih banyak bila dibanding dengan dengan subtipe B $(12,5 \%)$. CRF01_AE dominan ditemukan di Asia Tenggara dan juga menyebar luas di Thailand dan semenanjung Kamboja dengan jumlah penderita HIV mencapai satu juta orang. Selain itu, CRF01_AE juga telah dilaporkan tersebar di China, Vietnam, Malaysia, Myanmar, Laos, Korea Selatan, Taiwan, Philipina, dan Singapura. ${ }^{16}$

Kota Jayapura lebih banyak didapatkan subtipe B dibanding dengan CRF01_AE. Secara historis subtipe B umumnya terdapat di Eropa Barat, Amerika Utara, Amerika Latin, Jepang, Australia, dan Selandia Baru. Secara molekuler subtipe B pada penelitian ini masuk dalam kluster sekuens dari Amerika. Sementara itu distribusi global subtipe HIV-1 lebih berhubungan dengan perubahan sosial, ekonomi, dan imigrasi serta perjalanan internasional. Selain faktor tersebut, faktor geografis dan mobilitas penduduk juga memiliki peran penting dalam penyebaran dan keragaman genetik HIV- $1 .^{17}$

Proporsi jumlah CD4 yang tertinggi adalah $<200 \mathrm{sel} / \mathrm{mL}$ sebanyak 38 orang (40\%) dan yang terendah $>500 \mathrm{sel} / \mathrm{mL}$ sebanyak 14 orang (15\%). Tingginya jumlah penderita dengan CD4 $<200 \mathrm{sel} / \mathrm{mL}$ diakibatkan oleh penderita memeriksakan dirinya ketika infeksi oportunistik sudah muncul, padahal saat itu imunitas sudah menurun yang ditandai dengan jumlah CD4 di bawah normal. Dalam penelitian ini didapatkan subtipe HIV-1 tidak terbukti secara bermakna berhubungan dengan derajat penyakit \{jumlah CD4 dan stadium klinis $(\mathrm{p}=0,14)\}$, walaupun terdapat kecenderungan subtipenya CRF01_AE lebih banyak yang derajat penyakitnya lebih berat bila dibanding dengan subtipe B. Seperti penelitian di Thailand terhadap 185 pasangan yang salah satunya terinfeksi subtipe AE dan $\mathrm{B}$ menunjukkan probabilitas penularan pada pasangannya lebih tinggi pada subtipe CRF01_ 
AE (69\%) dibanding dengan subtipe B (48\%). ${ }^{18}$

Proporsi penderita AIDS yang paling tinggi adalah stadium klinis III sebanyak 38 orang (40\%) dan yang paling rendah dengan stadium 4 sebanyak 3 orang (3\%). Subtipe HIV-1 tidak terbukti secara signifikan berhubungan dengan derajat penyakit (stadium klinis), akan tetapi terdapat kecenderungan subtipe CRF01_AE lebih banyak derajat penyakitnya lebih berat dibanding dengan subtipe B. Dari penelitian ini didapatkan bahwa, prevalensi kasus dengan aktivitas terganggu (stadium 3 dan 4) pada subtipe CRF01_AE, yaitu sebesar $45 \%(p=0,59)$, sedangkan pada non CRF01_AE sebesar 43\%. Hal yang sama dengan penelitian yang dilakukan di Afrika didapatkan bahwa subtipe non B sering didapatkan pada pasien dengan penyakit derajat berat (stadium AIDS). ${ }^{19}$

Proporsi penderita AIDS dengan infeksi oportunistik tuberkulosis sebanyak 60 orang (64\%) dan juga penderita AIDS dengan infeksi oportunistik selain TB sebanyak 34 orang (36\%). Perbedaan tersebut secara statistik bermakna $(\mathrm{p}=0,00)$. Proporsi penderita HIV dengan subtipe B lebih tinggi (85\%) yang menderita infeksi oportunistik TB dibanding dengan penderita HIV non B. HIV/AIDS terkait dengan infeksi oportunistik terutama TB, respons pertahanan tubuh utama terhadap tuberkulosis diperantarai oleh imunitas seluler yang melibatkan respons limfosit $\mathrm{T}$ helper $\left(\mathrm{CD} 4^{+}\right)$dan limfosit $\mathrm{T}$ sitotoksik $\left(\mathrm{CD}^{+}\right)$. Di sisi lain, infeksi tuberkulosis juga akan meningkatkan progresivitas infeksi HIV. Risiko untuk mengalami infeksi oportunistik dan kematian lebih besar pada penderita yang mengalami koinfeksi HIV-TB dibanding dengan seseorang yang terinfeksi HIV tanpa TB. ${ }^{20}$

Simpulan, subtipe HIV-1 tersebut banyak ditemukan di Kota dan Kabupaten Jayapura adalah CRF01_AE dengan infeksi oportunistik yang paling banyak pada penderita adalah tuberkulosis. Tidak terdapat perbedaan subtipe HIV-1 dengan kadar CD4 dan stadium klinis, tetapi menunjukkan perbedaan antara subtipe HIV-1 dan infeksi oportunistik.

\section{Ucapan Terima Kasih}

Penulis mengucapkan terima kasih kepada penanggungjawab VCT RSUD Dok II, RSUD Abepura, dan RSUD Yowari yang telah membantu pelaksanaan pengambilan sampel. Rekan-rekan di laboratorium penyakit infeksi Prof. Oemijati Litbangkes Jakarta yang telah membantu proses analisis laboratorium.

\section{Daftar Pustaka}

1. Rubbert A, Behrens G, Ostrowski M. Pathogenesis of HIV-infection. Dalam: Hoffman C, Rockstroh JK, Kamps BS, penyunting. HIV medicine. Edisi ke-2. Paris: Flying Publisher; 2006. hlm. 62-4.

2. Ditjen PP \& PL Kemenkes RI. Statistik Kasus HIV/AIDS di Indonesia. Jakarta: Kemenkes RI; 2013.

3. Abecasis $\mathrm{AB}$, Annemarie MW, Dimitri $\mathrm{P}$, Jurgen V. HIV-1 subtype distribution and its demographic determinants in newly diagnosed patients in Europe suggest highly compartementalized epidemic. Retrovirology. 2013;10:1-13.

4. Yebra G, De Mulder M, Holguin A. Description of HIV-1 group m molecular epidemiology and drug resistance prevalence in equatorial Guinea from migrants in Spain. pLoS ONE. 2013;8(5):e64293.

5. Djoko DF, Rimoin AW, Vidal N, Tamoufe U, Wolfe ND, Butel C. HIV-1 type 1 group M Pol diversity and low rate of antiretroviral resistance mutations among the uniformed services in Kinshasa Democratic Republic of the Congo. AIDS Res Hum Retroviruses. 2011;27(30):323-9.

6. Chaplin B, Elisen G, Idoko J, Onwujekwa D. Impact of HIV type 1 subtype on drug resistance mutation in Nigeria patients failing first-line theraphy. AIDS Res Hum Retroviruses. 2011;27(1):71-80.

7. Buonaguro L, Tagliamonte $\mathrm{M}$, Tornesello $\mathrm{ML}$, Buonaguro FM. Genetic and phylogenetic evolution of HIV-1 in a alow subtype heterogenecity epidemic: the Italian example. Retrovirology. 2007;4(34):1-9.

8. Los Alamos National Laboratory. HIV circulating recombinant forms (CRFs) [online Journal] 2012 [diunduh 2 Juli 2012]. Tersedia dari: http://www.hiv.lanl.gov/ contentsequenceHIV/CRF/CRFs.html

9. Boonchawalid B, Jullaksorn D, Uttiyong J, Yowang A. Molecular evolution of HIV-1 CRF01_AE env in Thai patients. pLoS ONE. 2011;6:1-11.

10. Srisuphanut M, Sukeepaisarnchaeron W, Kucherer C, Pauli G. Epidemiology of HIV-1 subtypes in infected patients from Northeastern Thailand. Southeast Asian J Tropmed Public Health. 2004;35(3):641-6.

11. Dinas Kesehatan Provinsi Papua. Statistik kasus HIV/AIDS di Papua. [online Jornal] 2012 [diunduh 02 Juli 2014]. Tersedia dari: http://www.dinkes.papua.go.id 
12. Pohan HT. Infeksi di balik ancaman HIV. Jakarta: Farmacia; 2006.

13. Merati TP, Ryan C, Turnbul S, Wirawan DN, Otto B, Bakta IM. Subtipe HIV-1 di beberapa daerah di Indonesia dan perannya sebagai petunjuk dinamika epidemi HIV. Indonesian J Biomed Sci. 2008;2(2):1-25.

14. Wibowo HA, Setyawaty V, Salwati E. Epidemiologi moleculer genotipe HIV-1 pada ODHA di Jawa Timur dan DKI Jakarta. Buletin Penelitian Kesehatan. 2011;39(1):1-9.

15. Srisuphanut M, Sukeepaisarnchaeron W, Kuchererand C, Pauli G. Epidemiology of HIV-1 subtypes in infected patients from Northeastern Thailand. Southeast Asian J Tropmed Public Health. 2004;35(3):641-6.

16. Foley B, Donegan E, Silitonga N, Wignall F, Busch M, Delwart E. Important of multiple HIV type 1 strains into West Papua Indonesia (Irian Jaya). AIDS Res Hum Retroviruses. 2011;17:1655-9.
17. Gifford RJ, Oliveira T, Rambat A, Pybus OG, Dunn D, VanDamme AM. Phylogenetics surveilance of viral genetic diversity and the envolving molecular epidemiology of HIV type 1. J Virol. 2007;81(23):13050-6.

18. Praparattanapan J, Tragoslpua Y, Pathomaree W, Kotarathitium W, Chaiwarith R, Nuntacit $\mathrm{N}$, dkk. Current molecular epidemiology and recombination of HIV type 1 subtypes in Northern Thailand. AIDS Research and Human Retroviruses. 2011;27(11):1201-6.

19. Ataher Q, Portsmouth S, Napolitaro LA, Eng S, Grenacre A, Kambugo A, dkk. The epidemiology and clinical correlation of HIV 1 co-reseptor tropism in non-subtype $B$ infection from India, Uganda and South Africa. J Intern AIDS Society. 2012;15(1):2.

20. O'Garra A, Redford PS, McNab FW, Bloom CI, Wikinson RJ, Berry MP. The immune response in tuberculosis. Ann Rev Immunol. 2013;31:475-527. 